IFAS Extension

\title{
Bagworm, Thyridopteryx ephemeraeformis Haworth (Insecta: Lepidoptera: Psychidae) ${ }^{1}$
}

\author{
Brooke L. Moffis and Steven P. Arthurs²
}

\section{Introduction}

Approximately 1,000 species make up the family Psychidae, in which all species' larvae are enclosed in a bag and most species have flightless adult females. Bagworms can feed on many different plants, and Thyridopteryx ephemeraeformis (also called the evergreen bagworm, eastern bagworm,

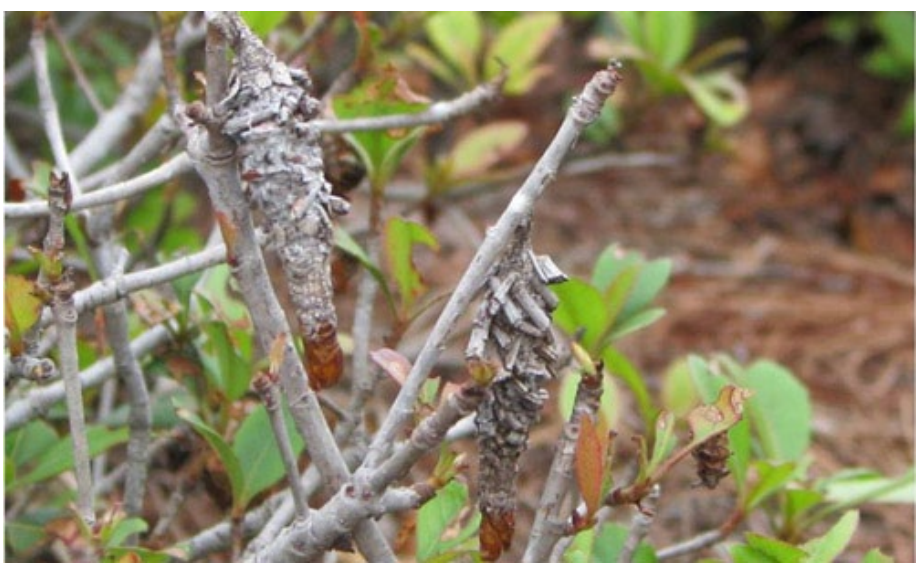

Figure 1. Bagworms and their damage on Indian hawthorn, Raphiolepis indica. Credits: Brooke L. Moffis, University of Florida.

common bagworm, common basket worm, or North American bagworm) can feed on over 50 families of deciduous and evergreen trees and shrubs (Rhainds et al. 2009). Severe infestations can damage the aesthetics and health of host plants, especially juniper (Juniperus) and arborvitae (Thuja) species, which are commonly grown in temperate climates (Ellis et al. 2005, Rhainds and Sadof 2008). Several species of bagworms can be found in Florida, Thyridopteryx ephemeraeformis is not found here in Florida with great frequency.

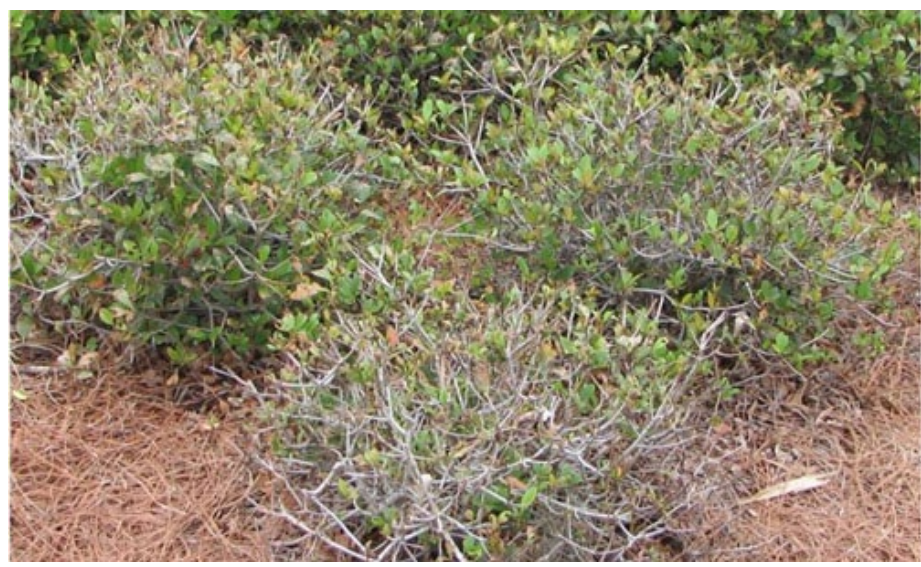

Figure 2. Defoliated Indian hawthorn, Raphiolepis indica, as a result of bagworm infestation.

Credits: Brooke L. Moffis, University of Florida.

\section{Distribution}

The family Psychidae is distributed widely in North, South, and Central America between Banff, Canada, to the southern tip of Argentina (Davis 1964). In North America, the bagworm is distributed throughout the eastern United States to Nebraska and as far north as southern Michigan in the Midwest U.S. (Rhainds and Fagan 2010).

1. This document is EENY-548, one of a series of the Entomology and Nematology Department, Florida Cooperative Extension Service, Institute of Food and Agricultural Sciences, University of Florida. Original publication date March 2013. Visit the EDIS website at http://edis.ifas.ufl.edu.

2. Brooke L. Moffis, graduate student; and Steven P. Arthurs, assistant professor, Mid-Florida Research and Education Center; Entomology and Nematology Department, Cooperative Extension Service, Institute of Food and Agricultural Sciences, University of Florida, Gainesville, FL 32611. 


\section{Description}

\section{Adults}

Adult bagworms will often go unnoticed in the landscape, especially the female, because she is enclosed in her bag and inside of her pupal casing throughout her life. In many species of bagworms, the adult female's wings and appendages are greatly reduced to vestigial mouthparts and legs, small eyes, and no antennae or wings. The female remains in a caterpillar-like state, mates, and then becomes essentially an egg-filled sac. The male bagworm emerges as a freely flying moth that is hairy and charcoal black. His membranous wings measure $25 \mathrm{~mm}$ in length (FDACS 1983). Neither the male nor the female adult feeds. The female lives a couple of weeks, while the male lives only one to two days (Rhainds et al. 2009).

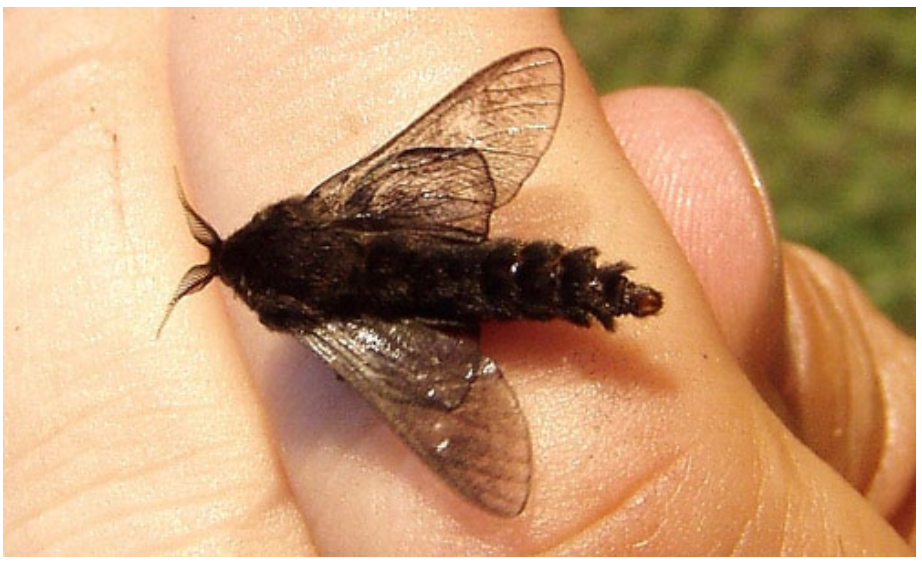

Figure 3. Adult male bagworm, Thyridopteryx ephemeraeformis. Credits: Curtis Young, Ohio State University.

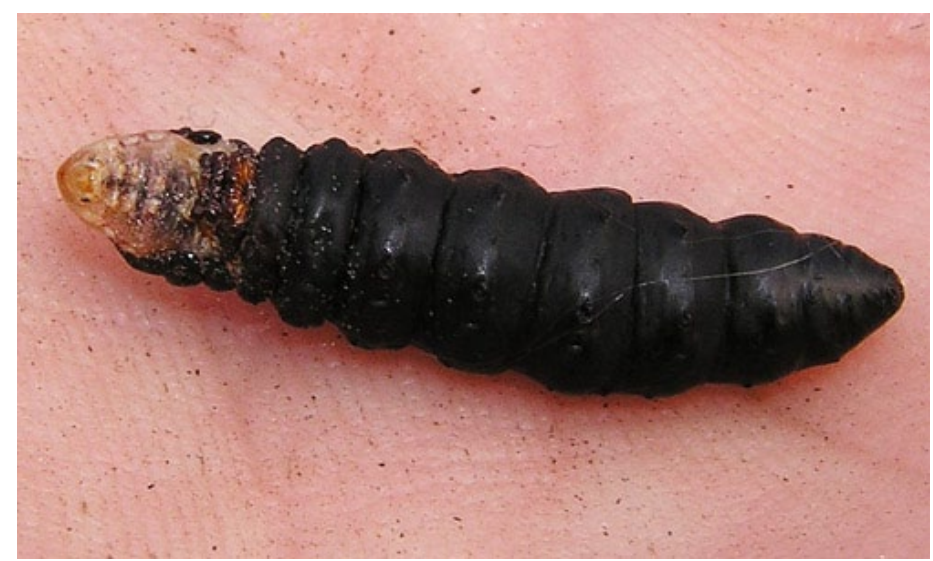

Figure 4. Adult female bagworm, Thyridopteryx ephemeraeformis. Credits: Curtis Young, Ohio State University.

\section{Eggs}

Shortly after mating, the female lays a large egg clutch (5001,000 eggs) inside of her pupal case enclosed within her bag. The eggs are smooth and cylindrical in shape and laid in a mass that is covered in a waxy, tuft-like layer (Peterson 1969).Bagworm eggs will overwinter.

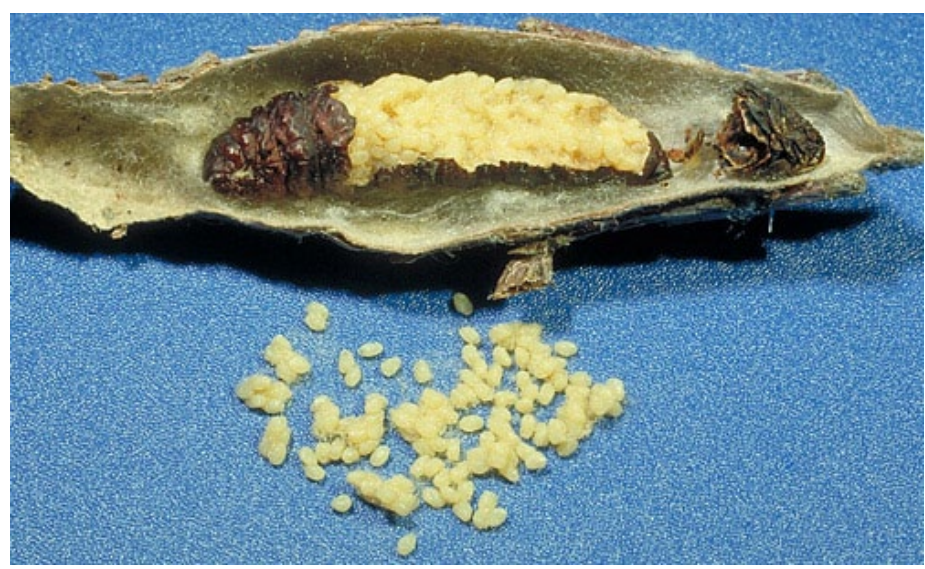

Figure 5. Bagworm eggs.

Credits: David J. Shetlar, Ohio State University.

\section{Larvae}

Hatching larvae are small (approximately $2 \mathrm{~mm}$ long) and often disperse to surrounding plants by spinning a silken thread and 'ballooning' on the wind. Once a suitable host is found, the caterpillar begins feeding and incorporating material into its bag, which it constructs with pieces of twigs, leaves, and silk (Peterson 1969). Only the head and the thorax emerge from the anterior end of the bag, so that the caterpillar can feed and move along plant material.

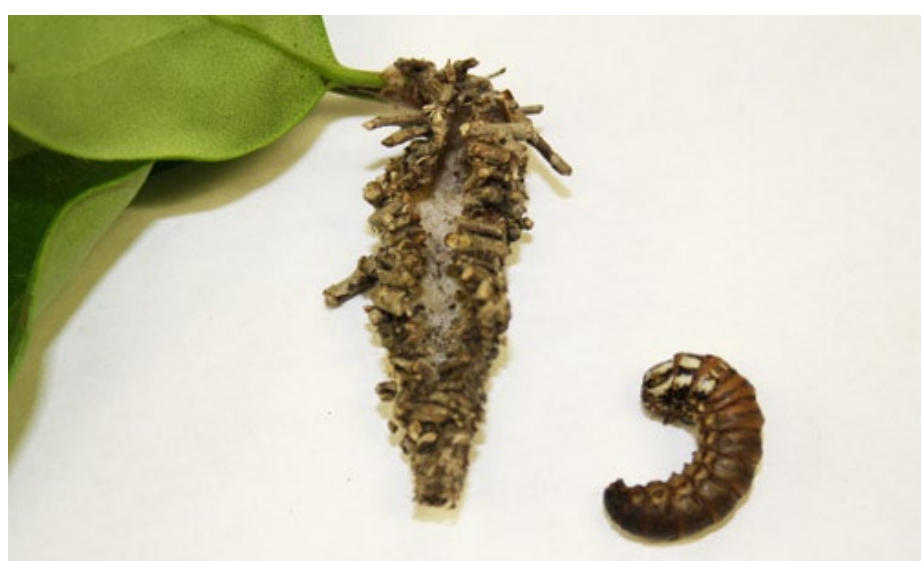

Figure 6. Bagworm larva removed from its bag. The bag is attached to Ligustrum. Credits: Luis Aristizabal, University of Florida. 


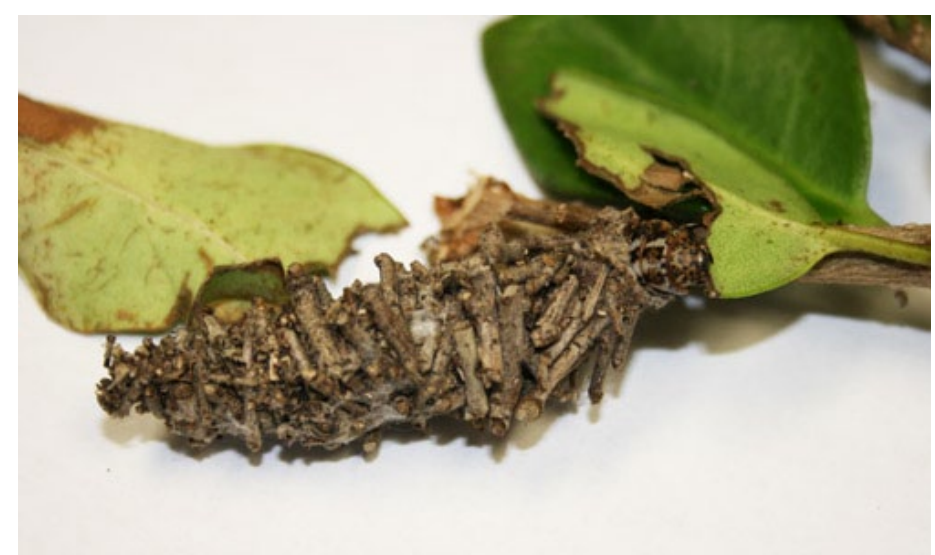

Figure 7. Bagworm larva feeding on Ligustrum. Credits: Brooke L. Moffis, University of Florida.

If the bag were to be dissected, the posterior end of the caterpillar would appear medium to dark brown in color with the dorsal portion of the first three segments being white to yellow with a dark brown pattern. The common bagworm caterpillar develops through seven instars before it transforms into a pupae (Rhainds and Sadof 2008). The fully grown larva is approximately $25 \mathrm{~mm}$ (1 inch) long and takes up to four months to develop, depending on temperature.

\section{Pupae}

The mature larva attaches its bag to a branch with a strong band of silk. The pupa remains inside the bag and is dark brown to black in color. The pupal stage generally lasts for 7-10 days.

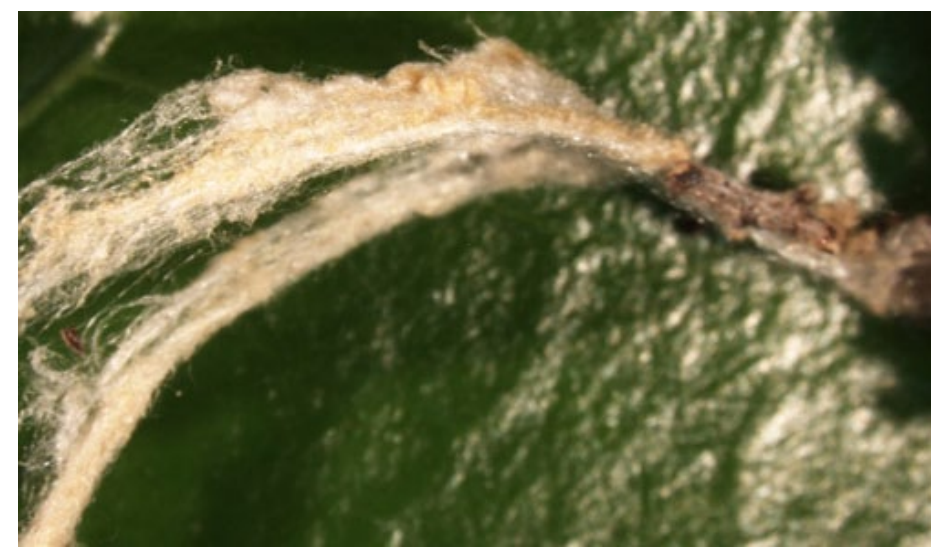

Figure 8. Silk strand produced by a bagworm larva. Photograph by Steven P. Arthurs, University of Florida

Credits: Steven P. Arthurs, University of Florida

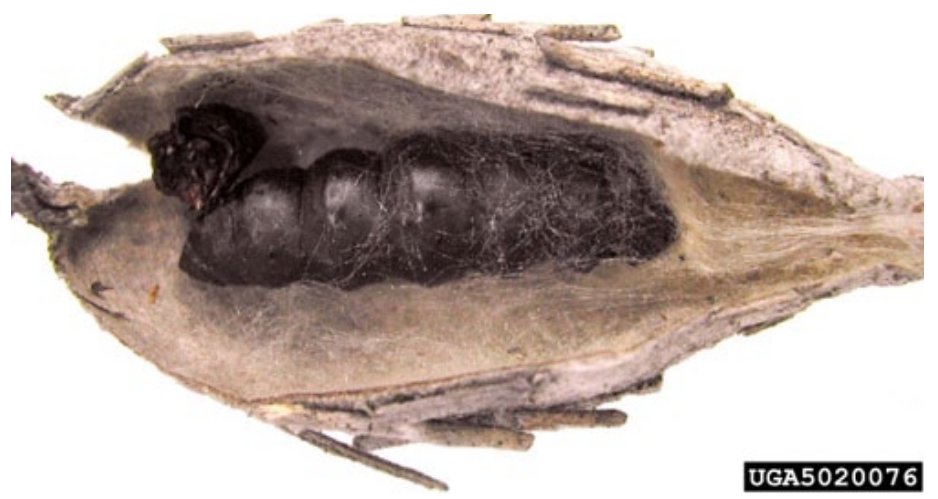

Figure 9. Common bagworm pupa.

Credits: Pennsylvania Department of Conservation and Natural Resources - Forestry Archive, Bugwood.org

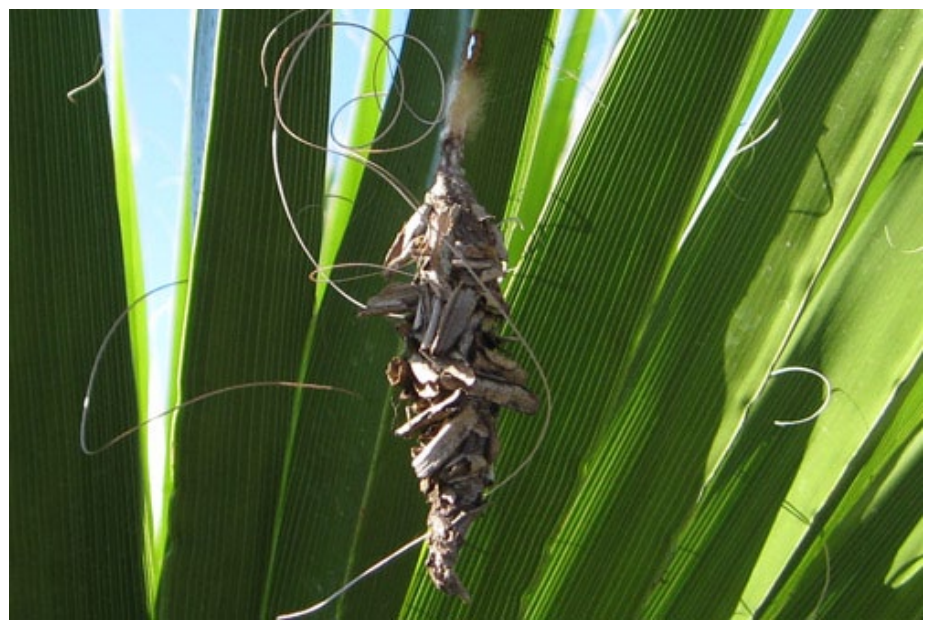

Figure 10. Bagworm pupae on Mexican fan palm. Credits: Steven P. Arthurs, University of Florida.

\section{Biology}

Throughout the U.S., the common bagworm has one generation per year and overwinters in the egg stage inside the female's pupal case. Other bagworm species may spend the winter as partially developed caterpillars. Common bagworm larvae hatch in late spring and early summer and may disperse with the wind via silken threads; if there is sufficient food, others may remain on the same host plant as their mother (Rhainds and Sadof 2008). Throughout the larval instars, the caterpillar increases the size of its bag as it grows and can survive long periods without food, especially during the later stages of development (Rhainds et al. 2009). Once the larva has consumed enough food during the last instar, it attaches its bag securely with a thick silken strand to its host plant or disperses to another structure. Prior to molting and pupation, the bagworm will seal the anterior portion of the bag (Leonhardt et al. 1983). 


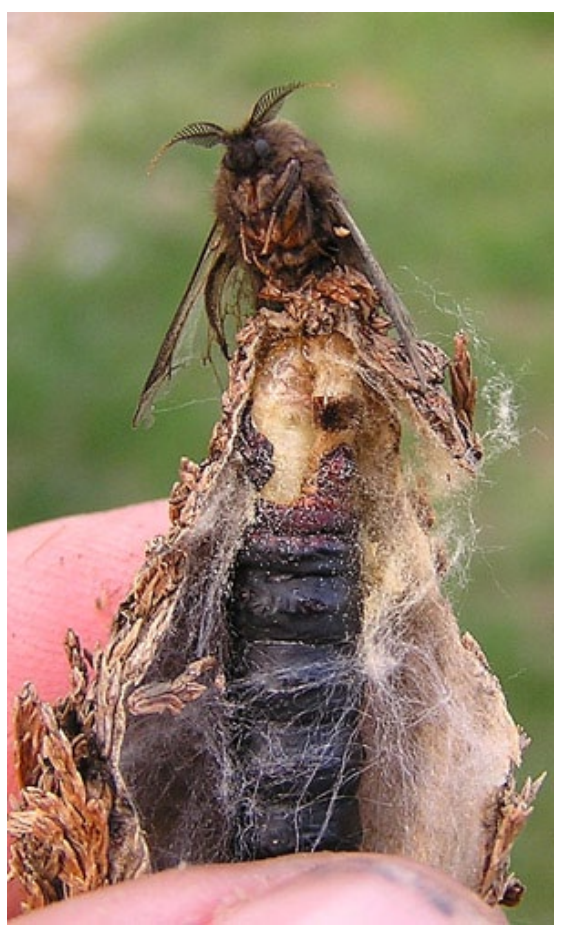

Figure 11. Male (top) and female bagworm.

Credits: Curtis Young, Ohio State University.

Adult males emerge in the fall while females release a pheromone that attracts the male moths. During mating, the male climbs onto the female's bag ,hangs upside down, and extends and inserts his abdomen about $4 \mathrm{~cm}$ into the bag (Leonhardt et al. 1983). Once mated, the female ceases production of pheromone and is no longer attractive to males (Rhainds et al. 2009). After oviposition, the female may die inside the bag, mummifying around her eggs, or may fall to the ground just before death (Peterson 1969, Rhainds et al. 2009).

\section{Host Plants}

Thyridopteryx ephemeraeformis can feed on over 50 families of deciduous and evergreen trees and shrubs. Common hosts include juniper (Juniperus spp.), arborvitae (Thuja spp.), live oak (Quercus virginiana), Southern red cedar (Juniperus silicicola), and willow (Salix spp.) (FDACS 1983). Other hosts include maple (Acer spp.), elm (Ulmus spp.), pine (Pinus spp.), Indian hawthorn (Raphiolepis indica), ligustrum (Ligustrum japonica), and viburnum (Viburnum spp.).

\section{Economic Importance}

The common bagworm is considered an occasional pest in Florida as many of the preferred host plants do not grow well below the USDA hardiness zone $8 \mathrm{~A}$. Due to its wide host range, high female fecundity, and method of dispersal, bagworm can still be problematic in the Florida landscape. In the northeastern and southern U.S., the common bagworm is one of the most damaging pests of urban trees. Less than $10 \%$ damage on woody plants is tolerated by consumers (Lemke et al. 2005), and during the summer months, as few as four bagworm larvae can cause a four-foot arborvitae to be unmarketable for sale (Sadof and Raupp 1987).

\section{Damage}

Initial feeding damage on evergreen trees causes branch tips to appear brown and unhealthy (Baxendale and Kalisch 2009). As the larvae become larger, their feeding damage becomes more apparent. During the summer, larvae can cause severe defoliation and even death, especially on evergreen species because their leaves are not replenished as readily as those of deciduous trees.

Bagworms can develop into localized infestations as larvae can move only a few meters from their mother's host plant resulting in high populations on some plants, while others nearby may experience very few bagworms. This method of dispersal can also lead to the same host plant experiencing bagworm populations year after year.

\section{Management Cultural control}

Handpicking bagworms and placing them in a bucket with soapy water or a sealed bag is an effective control method when populations are low and individuals can be reached easily (Lemke et al. 2005). Handpicking is most effective from late fall to early spring before adults reproduce and new bagworm larvae disperse.

\section{Chemical control}

When handpicking is not feasible, insecticide control should be aimed at young larvae. Penetration with insecticides can be challenging due to the protective bag. When feeding slows later in the season, control with insecticides may not be effective. 


\section{Biological insecticides}

Entomopathogenic bacteria (esp. Bacillus thuringiensis var. kurstaki) offer an effective means of control when applied to early instar larvae (Gill and Raupp 1994). Under certain weather conditions, entomopathogenic nematodes (esp. Steinernema carpocapsae) have been shown to provide control of bagworm larvae.

\section{Natural controls}

The common bagworm is attacked by at least 11 species of parasitic wasps (Balduf 1937). Ellis et al. (2005) found that the addition of flowering species to a mock landscape increased parasitism by the ichneumonid parasitoid wasps Pimpla disparis, Itoplectis conquisitor, and Gambrus ultimus. Predators of bagworms include white footed mice and sparrows (Ellis et al. 2005).

\section{Selected References}

Balduf WV. 1937. Bionomic notes on the common bagworm, Thyridopteryx ephemeraeformis Haw., (Lepid., Psychidae) and its insect enemies (Hym., Lepid.). Proceedings of the Entomological Society of Washington 39: 169-184.

Baxendale F, Kalisch JA. 2009. Bagworms. University of Nebraska Lincoln, NebGuide. G1951.

Davis DR. 1964. Bagworm moths of the Western Hemisphere. Bulletin U.S. National Museum, No. 244. 233 p., Washington D.C.

Ellis JA, Walter AD, Tooker JF, Ginzel MD, Reagel F, Lacey ES, Bennett AB,

Grossman EM, Hanks LM. 2005. Conservation biological control in urban landscapes: manipulating parasitoids of bagworm (Lepidoptera: Psychidae) with flowering forbs. Biological Control 34: 99-107.
FDACS. 1983. Insects of hardwood foliage bagworm. Bull. 196-A.

Gill SA, Raupp MJ. 1994. Using entomopathogenic nematodes and conventional and biorational pesticides for controlling bagworm. Journal of Arboriculture 20: 318-322.

Lemke HD, Raupp MJ, Shrewsbury PM. 2005. Efficacy and costs associated with the manual removal of bagworms, Thyridopteryx ephemeraeformis, from leyland cypress. Journal of Environmental Horticulture 23:123-126.

Leonhardt BA, Neal JW, Klun JA, Schwarz M, Plimmer JR. 1983. An unusual lepidopteran sex pheromone system in the bagworm moth. Science 219: 314-316.

Peterson A. 1969. Bagworm photographs: eggs, larvae, pupae, and adults of Thyridopteryx ephemeraeformis (Psychidae: Lepidoptera). The Florida Entomologist 52: 61-72.

Rhainds M, Fagan WF. 2010. Broad-scale latitudinal variation in female reproductive success contributes to the maintenance of a geographic range boundary in bagworms (Lepidoptera: Psychidae). PLoS One 5(11):e14166.

Rhainds M, Davis DR, Price PW. 2009. Bionomics of bagworms (Lepidoptera: Psychidae). Annual Review of Entomology 54: 209-226.

Rhainds M, Sadof CS. 2008. Elements of population dynamics (Lepidoptera: Psychidae) on hedge rows of white pine. Annals of the Entomological Society of America 101: 872-880.

Sadof CS, Raupp MJ. 1987. Consumer attitudes toward the defoliation of American arborvitae, Thuja occidentalis, by bagworm, Thyridopteryx ephemeraeformis. Journal of Environmental Horticulture 5: 164-166.

Shetlar DJ. 2010. Bagworm and its control. The Ohio State University Extension Article HGY-2149-10. 